\title{
SOIL CHARACTERISTICS UNDER INTENSIFIED SHIFTING CULTIVATION FOR UPLAND RICE CULTIVATION IN UPLAND SABAL, SARAWAK, MALAYSIA
}

\author{
HO SOO YING*, MOHD EFFENDI BIN WASLI and MUGUNTHAN PERUMAL \\ Department of Plant Science and Environmental Ecology, Faculty of Resource Science and Technology, \\ Universiti Malaysia Sarawak, 94300 Kota Samarahan, Sarawak, Malaysia
}

Received16 January 2017/Accepted 12 September 2017

\begin{abstract}
Shifting cultivation practices are regarded as the most important agricultural land-use in the marginal uplands of Sarawak for the livelihood of the rural communities. In response to various socio-economic consequences, previous practices on traditional form of shifting cultivation were altered into much sedentary farming practices. Soil productivity to sustain rice yield under current intensified forms of shifting cultivation should be of prime importance for food security among the local community at the marginal uplands of Sarawak. Therefore, this study was conducted to characterize soil properties influenced by the current intensified shifting cultivation practices at Sabal upland area, Sarawak. Along with the use of agrochemicals, shifting cultivation at Sabal area was conducted through single cultivation practices (10 to 15 years of fallow period and a cycle of rice cultivation) and multiple cultivation practices (5 to 7 years of fallow period and two cycles of rice cultivation). Before burning practices, soil $\mathrm{pH}$ was highly acidic (ranged from 4.28 to 4.72) in single cultivation sites; while multiple cultivation sites showed less acidic nature (soil pH ranged from 4.98 to 5.23) with relatively high secondary macronutrient contents, especially soil exchangeable $\mathrm{Mg}$ and $\mathrm{Ca}$. No significant observation was found after burning practice in Total $\mathrm{C}$ and Total $\mathrm{N}$ of the soils at both sites. The level of soil exchangeable bases $(\mathrm{K}, \mathrm{Mg}$ and $\mathrm{Ca}$ ) and available $\mathrm{P}$ increased after the burning practices in single cultivation farmlands; while multiple cultivation sites showed lower to no increase in exchangeable bases and available $\mathrm{P}$, partly attributed to the limited supply of nutrients from the aboveground biomass. After the harvesting of rice, soils at both sites tended to be more acidic and lower in macronutrient contents ( $\mathrm{K}, \mathrm{Mg}$ and $\mathrm{Ca}$ ), primarily ascribable to crop uptake during the cultivation period. The average yield of rice in single cultivation sites and multiple cultivation sites were $721 \mathrm{~kg} / \mathrm{ha}$ and $391 \mathrm{~kg} / \mathrm{ha}$, respectively. Our findings suggested that the usage of agrochemicals, particularly fertilizers in multiple cultivation sites are necessary for sustaining rice yield to restore the depleted macronutrients (especially $\mathrm{K}, \mathrm{Mg}$ and $\mathrm{Ca}$ ) after successive cultivation.
\end{abstract}

Keywords: Intensive, macronutrients, shifting cultivation, soil characteristics, upland rice field, upland Sarawak

\section{INTRODUCTION}

Shifting cultivation is an old, primitive and predominant land-use system in remote mountainous areas of many regions across the globe. For decades, the Dayak tribe, including the Ibans' and the Bidayuhs' in Sarawak practices shifting cultivation of upland rice as their source of staple food (Kleinman et al. 1995). Teng (1993) reported that the annual rate at which land is cleared by the local people in Sarawak ranges from 75,000 to 150,000 ha or 0.6 to $1.2 \%$ of the total land areas; while $2.7 \times 10^{6}$ ha or $22 \%$ of the state

\footnotetext{
* Corresponding author: sherylsooying@gmail.com
}

land is either underused or had been used at least once for shifting cultivation. Such agricultural system could be regarded as ecologically sound and sustainable under the condition of low population density, poor soil fertility and inaccessibility to market (Fox et al. 2000; Mertz 2002; Ickowitz 2006; Nielson et al.2006).

In recent decades, scarcity of arable land resources due to population expansion and urban development resulted in gradual alteration of traditional shifting cultivation practices. It is said that current form of shifting cultivation practice is intensified with the shortening of fallow length, longer cultivation period and incorporation of agrochemicals, especially fertilizers in their 
farming practices (Ichikawa 2004; Kendawang et al. 2005; Wasli et al. 2009). In reality, some farmers continuously cultivate upland rice at the same land for few cycles. Shortened fallow period caused insufficient recovery of vegetation and soils for the next cultivation, indirectly resulting to the decreasing crop productivity, increasing pest and disease cases and declining of soil fertility. Additionally, applications of agrochemicals especially fertilizers and pesticides are widely practiced by the local farmers partly due to subsidy scheme provided by local government agencies. As the modification in the current intensified shifting cultivation practice remained unapprehended in Sarawak especially in the aspect of soil agroecology, there is a need to obtain fundamental information on the suitability of current state of modified shifting cultivation practices toward sustaining the livelihood and subsistence of the local farmers in the upland agroecosystem of Sarawak.

Few studies were conducted mainly on the effect and impacts of shifting cultivation to soil ecosystems (Cramb 1989; Funakawa et al. 1997; Kendawang et al. 2004; Tanaka et al. 2004; Etsuko et al. 2004; Kendawang et al. 2005; Bruun et al. 2009; Wasli et al. 2011). Some researchers reported on the current practices involving shorter fallow period and continuous cultivation for few cycles in Sarawak (Kendawang et al. 2004; Bruun et al. 2006; Wasli et al. 2009). In addition, Dalle and de Blois (2006) pointed out that reduction of fallow cycles caused a decline in noncrop plant resources especially in pioneer species and an increase in short-lived weedy species. However, none of their studies discussed the outcome of recent intensified shifting cultivation, with special reference to soil physicochemical aspects under different stages of shifting cultivation cycles. Present study is necessary to obtain the baseline information on soil fertility as one of the primary indicator of sustaining upland agriculture productivity, soil resources, selfsubsistence and livelihood of the upland communities in Sarawak. Thus, this study was aimed to characterize soil physicochemical properties under current intensified shifting cultivation practices at Sabal upland area, Sarawak. Previously, Kendawang et al. (2004) studied soil fertility in this area based on conventional shifting cultivation practices. They concluded that soils at Sabal area were naturally infertile and difficult for the farmers to sustain rice production through traditional form of shifting cultivation practices under such soil condition.

\section{MATERIALS AND METHODS}

\section{Study Area}

The study was conducted at Sabal upland area (01 04'24.6" N, 11058'08.6” E), Sarawak, Malaysia as shown in Figure 1.

The study area consisted of mainly undulating hills which extended to steep and mountainous Klingkang range where it meets the border of Kalimantan, Indonesia. Sabal is located about $110 \mathrm{~km}$ from south-east of Kuching City and is accessible by Kuching-Sri Aman central road. Local communities resided in the study area are mainly of Iban origin for approximately 100 years. The climate condition of the study area is tropical climate with a mean annual temperature of approximately $32.5{ }^{\circ} \mathrm{C}$ and negligible monthly variation throughout the year (Meteorological Department 2014). The average mean precipitation is about $3,585 \mathrm{~mm}$ obtained from the nearest weather station located at Sri Aman Airport (Meteorological Department 2014). Soils in the study area were derived from non-calcareous sedimentary rock consisting of fine and whitish sandstone which is further classified into Oxyaquic or Spodic Quartzipsamments based on USDA Classification System (Butt 1983; Soil Survey Staff 1999). Most of the villagers are farmers cultivating subsistence crops such as upland rice, fruits and vegetables as well as other cash crops i.e. rubber, pepper and oil palm.

\section{Site Selection and Agronomic Practices in Relation to Upland Rice Cultivation}

Field survey was conducted from August 2013 to March 2014. Prior to soil sampling, community survey via Rapid Rural Appraisal (RRA) approach was conducted to collect baseline information on family background, land-use history and crop management practices. Desirable sites were selected based on the availability of farmlands with shifting cultivation i.e. single cultivation and multiple cultivation practices. Single cultivation practice refers to the long fallow period with short cultivation period. Multiple cultivation practice 
refers to the short fallow period with long cultivation period. Farmers' perception on site suitability for rice cultivation is based on their traditional knowledge, typically through soil observation and vegetation composition of the desired lands. Accessibility and location of the farmlands were particularly important in farmer's decision for site selection.

Overall, a total of 8 sites for both single cultivation farmlands $(\mathrm{n}=4)$ and multiple cultivation farmlands $(n=4)$ were selected after interviews. The slope gradients for all study sites ranged from 12 to $20^{\circ}$ with elevation ranged from 23 to $88 \mathrm{~m}$ above sea level. Land-use history of all study sites was illustrated in Table 1 .

Single cultivation sites were fallowed for 11 to 15 years; while multiple cultivation sites had shorter fallow period of 5 to 7 years with continuous cultivation for two cycles, thus intensified. Farmlands size usually depended on the numbers of family members and availability of manpower in managing the farmlands. At Sabal area, the farmland sizes ranged from 0.47 to 3.82 ha with an average of 1.86 ha. Agrochemicals such as fertilizers and pesticides subsidized by government agencies were widely used in the current farming practices, either in single cultivation or in multiple cultivation practices. Fertilizers were applied under single cultivation practices. Unlike research results reported previously in Tanaka et al. (2007a) at Mujong River area, previous conventional single cycle of shifting cultivation involved no fertilizers application. Compound N-P-K (17.5-15.5-10.0) and urea $(46 \%)$ were commonly used in both cultivation practices. The application rate of fertilizers generally varied among the household with an average application rate of $132 \mathrm{~kg} / \mathrm{haper}$ cycle for single cultivation sites and $190 \mathrm{~kg} / \mathrm{ha}$ per cycle for multiple cultivation sites, giving rise to average N-P-K (40-10-7) kg/ha/year and N-P-K (64-13-8) $\mathrm{kg} / \mathrm{ha} /$ year for single and multiple upland rice cultivation, respectively. In addition, herbicides and pesticides were commonly applied in both cultivation practices during land preparation and rice farming period. Based on the farmers' experience, agrochemicals requirements under multiple cultivation sites were generally higher compared to single cultivation sites due to factors such as weeds and pest infestation. Thus, multiple cultivation sites were regarded as intensified in terms of reduction of fallow age, laborious farm work maintenance and higher rate of agrochemicals application.

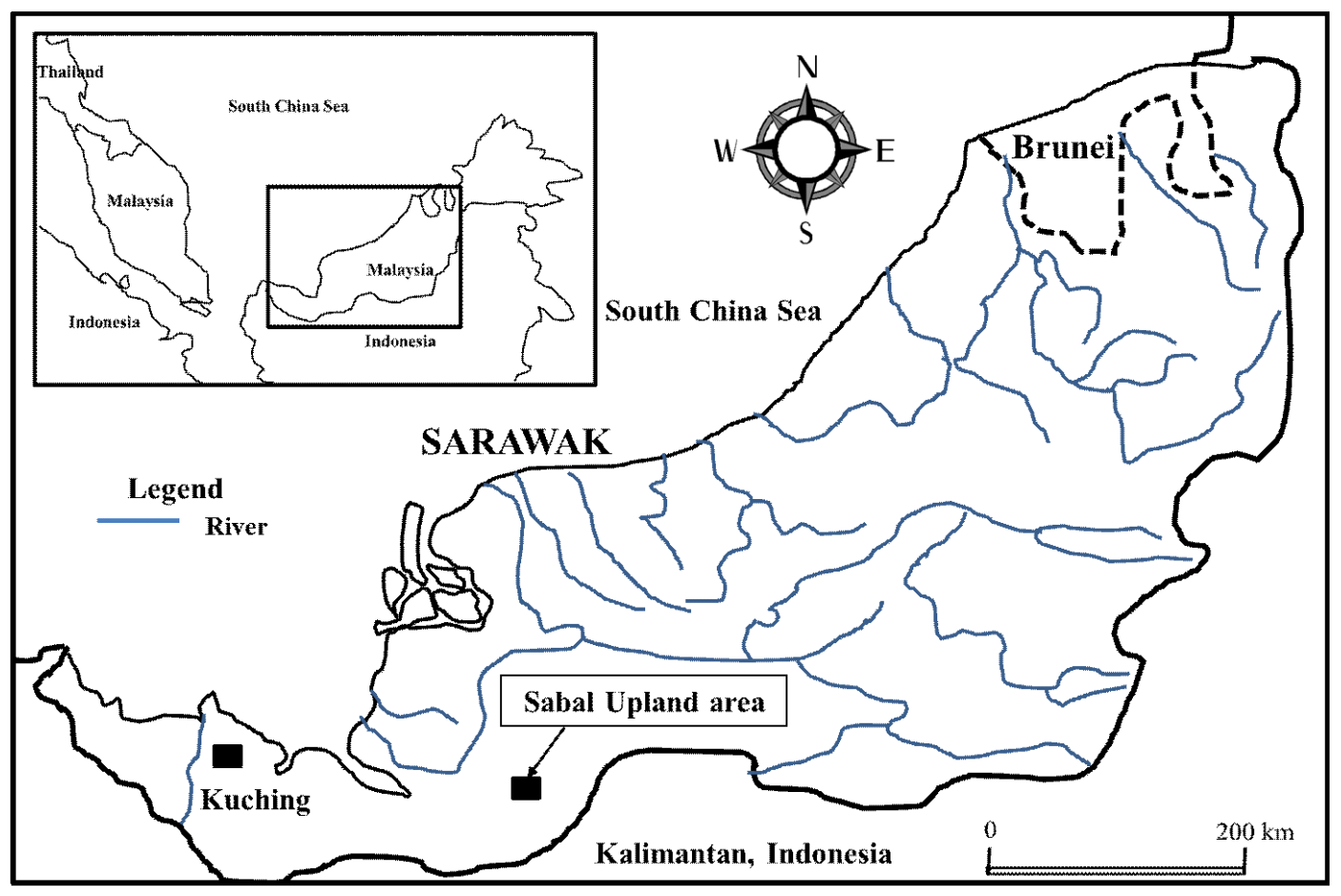

Figure 1 Map of the study area 
Table 1 Land-use history of the selected study sites

\begin{tabular}{|c|c|c|c|c|c|c|c|c|c|c|c|c|c|c|}
\hline \multirow{2}{*}{ Sites } & \multicolumn{14}{|c|}{ Land-use history (year) } \\
\hline & 2013 & 2012 & 2011 & 2010 & 2009 & 2008 & 2007 & 2006 & 2005 & 2004 & 2003 & 2002 & 2001 & 2000 \\
\hline \multicolumn{15}{|c|}{ Single Cultivation (SC) } \\
\hline SC1 & $\mathrm{R}$ & & & & & & & & & & & & & $\mathrm{R}$ \\
\hline SC2 & $\mathrm{R}$ & & & & & & & & & & & & & \\
\hline SC3 & $\mathrm{R}$ & & & & & & & & & & & & & \\
\hline SC4 & $\mathrm{R}$ & & & & & & & & & & & & $\mathrm{R}$ & \\
\hline \multicolumn{15}{|c|}{ Multiple Cultivation (MC) } \\
\hline MC1 & $\mathrm{R}$ & $\mathrm{R}$ & & & & & & $\mathrm{R}$ & $\mathrm{R}$ & & & & & $\mathrm{R}$ \\
\hline MC2 & $\mathrm{R}$ & $\mathrm{R}$ & & & & & & $\mathrm{R}$ & & & & & & $\mathrm{R}$ \\
\hline MC3 & $\mathrm{R}$ & $\mathrm{R}$ & & & & & & & & $\mathrm{R}$ & $\mathrm{R}$ & & & \\
\hline MC4 & $\mathrm{R}$ & $\mathrm{R}$ & & & & & & & $\mathrm{R}$ & & & & & $\mathrm{R}$ \\
\hline
\end{tabular}

Note: $\mathrm{R}=$ upland rice cultivation; $\quad$ = fallow period

\section{Soil Sampling and Analysis}

Soil samples were collected at 3 different phases of a typical shifting cultivation cycle, notably before burning (BB) of dried vegetation after land clearing (August), after burning (AB) of the dried vegetation (September) and after harvesting (AH) of upland rice (February) in 2013 and 2014, respectively. The yield of upland rice in each farmland at single and multiple sites were recorded as well. Composite soil samples were collected within two weeks' period of each phase at soil depth of $0-10 \mathrm{~cm}$ and $30-40 \mathrm{~cm}$ from three random points within the same location at the farmland area. On the other hand, core samples $\left(100 \mathrm{~cm}^{3}\right)$ were collected from the same depth in triplicates for soil bulk density determination. Composite soil samples collected were air-dried and crushed to pass through sieves with $2 \mathrm{~mm}$ mesh for the determination of soil physicochemical properties.

Soil $\mathrm{pH}\left(\mathrm{H}_{2} \mathrm{O}\right)$ was determined in water. Soil $\mathrm{pH}(\mathrm{KCl})$ in $1 \mathrm{M} \mathrm{KCl}$ was determined in a soil to solution ratio of 1:5 using glass electrode method. Electrical conductivity (EC) was measured after the $\mathrm{pH}\left(\mathrm{H}_{2} \mathrm{O}\right)$ measurement using EC meter. Total $\mathrm{C}$ is determined by loss on ignition method (Dean 1974). Total $\mathrm{N}$ was determined by Kjeldahl acid digestion and measured by colorimeter method. Contents of exchangeable bases and the Cation Exchange Capacity (CEC) were measured respectively, after successive extraction using $1 \mathrm{M}$ ammonium acetate adjusted to $\mathrm{pH} 7.0$ and 10\% $\mathrm{NaCl}$. Contents of exchangeable bases were determined using Atomic Absorption Spectrophotometry (AAS) for $\mathrm{Ca}, \mathrm{Mg}, \mathrm{K}$ and $\mathrm{Na}$ (Coleman et al. 1959). Exchangeable $\mathrm{Al}$ and $\mathrm{H}$ were extracted with $1 \mathrm{M} \mathrm{KCl}$ from $\mathrm{pH}(\mathrm{KCl})$ filtrates. Exchange acidity $(\mathrm{Al}+\mathrm{H})$ was determined using titration method with $0.01 \mathrm{M}$ $\mathrm{NaOH}$. Content of exchangeable $\mathrm{Al}$ was determined with $0.01 \mathrm{M} \mathrm{HCl}$. Content of exchangeable $\mathrm{H}$ was calculated as the difference between the values of the exchange acidity and exchangeable Al. Available P was quantified using Bray II method (Kuo 1996). In Bray II method, soil samples were extracted with extracting solution consisted of $1 \mathrm{M} \mathrm{NH} \mathrm{N}_{4} \mathrm{~F}$ and $0.5 \mathrm{M} \mathrm{HCl}$. Color developing reagent was then added into the extract. Available phosphorus was determined by absorbance measurement with UV spectrophotometer at wavelength of $710 \mathrm{~nm}$ (Bray \& Kurtz 1945). Particle size distribution was determined using pipette method with the assistance of soil textural class (Gee \& Bauder 1986); while soil hardness was measured by Yamanaka-type push cone penetrometer.

\section{Data Analyses}

All statistical analyses were performed using SPSS Version 22 (SPSS Inc.) for comparison of soil physicochemical properties between single and multiple cultivation practices using Student's $t$-Tests. Relationships among yield and fallow period, fertilizers applied as well as soil physicochemical properties were computerized using Pearson's Correlation Coefficients. 


\section{RESULTS AND DISCUSSION}

\section{Soil Physicochemical Properties under Shifting Cultivation at the Study Area}

Table 2 presented the average values of surface and subsurface soil physicochemical properties at different stages of shifting cultivation cycle in relation to single cultivation and multiple cultivation practices at Sabal area.

At all stages, no substantial differences were observed for average surface and subsurface soil properties between single and multiple cultivation sites. It is noteworthy that the discussion of current study was mainly focused on the surface soil layer $(0-10 \mathrm{~cm})$ rather than on the subsurface soil layer $(30-40 \mathrm{~cm})$. The effect of burning practice was not distinct at the subsurface layer (Kumada et al. 1985; Kyuma et al. 1985; Tanaka et al. 2001; Kendawang et al. 2004; Kendawang et al. 2005). However, the properties of the subsoil layer should be obtained to clarify if any significant changes in terms of soil physicochemical properties were observed under current intensified multiple cultivation practices adapted by the local farmers at the study area.

Previous study by Kendawang et al. (2004) reported that the soils at Sabal area were characterized by relatively sandy texture and low nutrient contents. Soil Organic Matter (SOM) in the surface soils was visible, mainly composed of coarse fragments of plant debris; while clay mineral composition was dominated by kaolin minerals, and to a lesser extent by quartz (Kendawang et al. 2004).

Soil $\mathrm{pH}\left(\mathrm{H}_{2} \mathrm{O}\right)$ under single cultivation sites were acidic (ranging from 4.28 to 4.72 ) before burning practices; while soil $\mathrm{pH}\left(\mathrm{H}_{2} \mathrm{O}\right)$ value showed an increase to the range from 4.54 to 5.23 after burning practices (Table 2). Later, soil $\mathrm{pH}$ $\left(\mathrm{H}_{2} \mathrm{O}\right)$ decrease slightly to the range of 4.40 to 5.16 after harvesting of the upland rice. In contrast, soil $\mathrm{pH}\left(\mathrm{H}_{2} \mathrm{O}\right)$ under multiple cultivation sites showed gradual decrease with the average of 5.11 at before burning to 4.83 after burning and further decrease to 4.65 after harvesting stages. Before burning practice significantly lower soil $\mathrm{pH}\left(\mathrm{H}_{2} \mathrm{O}\right)$ values in single cultivation sites due to the vigorous uptake of basic cations by the existing vegetation during fallow period (Tanaka et al. 1997; Wasli et al. 2011). Multiple cultivation sites with lower fallow period were less acidic indicating the remnant ash effects from previous burning practices and fertilizers residues from previous year. After burning practices, soil $\mathrm{pH}\left(\mathrm{H}_{2} \mathrm{O}\right)$ showed an increase from 4.56 to 4.90 at single cultivation sites compared to multiple cultivation sites, mainly caused by direct effect of ash addition into the surface soil. Various studies reported that burning practice significantly increases soil $\mathrm{pH}$ due to acid neutralizing capacity of ash (Nye \& Greenland 1964; Kyuma et al. 1985; Armando et al. 1996). In contrast, such effect was not observed in multiple cultivation sites after the burning practice. Shortening of fallow period in multiple cultivation sites has led to poor vegetation regrowth, which in turn limiting the ash input to soils during burning to alleviate soil acidity (Wasli et al. 2009). Soil $\mathrm{pH}\left(\mathrm{H}_{2} \mathrm{O}\right)$ was further acidified after the harvesting phase in both cultivations. Soil acidity was mainly caused by the removal of basic cations in the soils from the uptake of the upland rice crops (Tulaphitak et al. 1985; Gafur et al. 2000; Biswas et al. 2012). However, it can be observed that soil acidity was more pronounced in multiple cultivation sites due to the depletion of nutrients after the second cycle of upland rice cropping.

In our study, soil Total $\mathrm{C}$ and Total $\mathrm{N}$ varied widely among the stages under both types of cultivation practices. In the surface layer, Total C of the soil ranged from $14.2 \mathrm{~g} / \mathrm{kg}$ to $40.3 \mathrm{~g} / \mathrm{kg}$; while Total $\mathrm{N}$ of the soil ranged from $0.97 \mathrm{~g} / \mathrm{kg}$ to $3.00 \mathrm{~g} / \mathrm{kg}$. Present studies showed no remarkable changes in Total $\mathrm{C}$ and Total $\mathrm{N}$ of the soil after burning practice at both single and multiple cultivation sites. In fact, the contents of Total C and Total $\mathrm{N}$ in most single and multiple cultivation sites, decreased after burning practices which is in agreement with results of previous findings (Ewel et al. 1981; Andriesse \& Schelhaas 1987; Hölscher et al. 1997; Gafur et al. 2000; Tanaka et al. 2001). Unlike those reported by various researchers (Nye \& Greenland 1964; Kyuma et al. 1985; Tulaphitak et al. 1985), significant increase in Total $\mathrm{C}$ and Total $\mathrm{N}$ of the soil were usually found after burning practices. Several sites (both single and multiple) showed a slight increase of Total $\mathrm{C}$ and Total $\mathrm{N}$ after burning. In their study at Northeast Thailand, Kyuma and Pairintra (1983) investigated that burning resulted in partially carbonized litter added into the soil. However, our study showed that the $\mathrm{C} / \mathrm{N}$ ratio in all both single and multiple 
Table 2 Surface and subsurface soil physicochemical properties under different stages of shifting cultivation cycle in single cultivation and multiple cultivation farmlands

\begin{tabular}{|c|c|c|c|c|c|c|c|}
\hline \multirow{2}{*}{\multicolumn{2}{|c|}{$\begin{array}{l}\text { Soil physicochemical } \\
\text { properties }\end{array}$}} & \multicolumn{2}{|c|}{ Before Burning (BB) } & \multicolumn{2}{|c|}{ After Burning (AB) } & \multicolumn{2}{|c|}{ After Harvesting (AH) } \\
\hline & & $\mathrm{SC}^{\mathrm{a}}$ & $\mathrm{MC}^{\mathrm{b}}$ & SC & $\mathrm{MC}$ & SC & $\mathrm{MC}$ \\
\hline \multicolumn{8}{|c|}{ Surface Soil $(0-10 \mathrm{~cm})$} \\
\hline $\mathrm{pH}\left(\mathrm{H}_{2} \mathrm{O}\right)$ & & $4.56 \pm 0.19 *$ & $5.11 \pm 0.11 *$ & $4.90 \pm 0.24$ & $4.83 \pm 0.08$ & $4.76 \pm 0.35$ & $4.65 \pm 0.16$ \\
\hline $\mathrm{EC}$ & $\mu \mathrm{S} / \mathrm{cm}$ & $51 \pm 29 *$ & $39 \pm 6^{*}$ & $55 \pm 24$ & $41 \pm 2$ & $33 \pm 10$ & $29 \pm 5$ \\
\hline Total C & $\mathrm{g} / \mathrm{kg}$ & $26.0 \pm 12.9$ & $26.2 \pm 7.1$ & $23.3 \pm 9.7$ & $23.8 \pm 6.4$ & $24.2 \pm 7.6$ & $21.2 \pm 3.2$ \\
\hline Total N & $\mathrm{g} / \mathrm{kg}$ & $1.9 \pm 0.9$ & $1.7 \pm 0.2$ & $1.9 \pm 0.6$ & $1.7 \pm 0.3$ & $1.4 \pm 0.3$ & $1.3 \pm 0.1$ \\
\hline $\mathrm{C} / \mathrm{N}$ & & $13.5 \pm 1.3$ & $16.0 \pm 4.6$ & $12.3 \pm 1.1$ & $13.7 \pm 2.4$ & $17.4 \pm 2.2$ & $16.6 \pm 1.9$ \\
\hline CEC & $\mathrm{cmol}_{\mathrm{c}} / \mathrm{kg}$ & $3.45 \pm 1.91$ & $5.15 \pm 1.80$ & $3.75 \pm 1.46$ & $2.95 \pm 0.75$ & $3.35 \pm 1.66$ & $2.65 \pm 0.50$ \\
\hline Exch. $\mathrm{K}^{+}$ & $\mathrm{cmol}_{\mathrm{c}} / \mathrm{kg}$ & $0.05 \pm 0.04$ & $0.07 \pm 0.02$ & $0.19 \pm 0.10$ & $0.10 \pm 0.05$ & $0.12 \pm 0.08$ & $0.06 \pm 0.01$ \\
\hline Exch. $\mathrm{Mg}^{2+}$ & $\mathrm{cmol}_{\mathrm{c}} / \mathrm{kg}$ & $0.15 \pm 0.11$ & $0.27 \pm 0.26$ & $0.28 \pm 0.08$ & $0.26 \pm 0.09$ & $0.29 \pm 0.11$ & $0.18 \pm 0.02$ \\
\hline Exch. $\mathrm{Ca}^{2+}$ & $\mathrm{cmol}_{\mathrm{c}} / \mathrm{kg}$ & $0.31 \pm 0.27$ & $0.50 \pm 0.50$ & $1.01 \pm 0.54$ & $0.48 \pm 0.18$ & $0.68 \pm 0.28^{*}$ & $0.34 \pm 0.05^{*}$ \\
\hline Exch.Al ${ }^{3+}$ & $\mathrm{cmol}_{\mathrm{c}} / \mathrm{kg}$ & $0.81 \pm 0.52$ & $0.76 \pm 0.20$ & $0.83 \pm 0.43$ & $0.51 \pm 0.32$ & $0.97 \pm 0.79$ & $0.61 \pm 0.20$ \\
\hline $\mathrm{ECEC}^{\mathrm{c}}$ & $\%$ & $1.37 \pm 0.72$ & $1.74 \pm 0.74$ & $2.34 \pm 0.88$ & $1.38 \pm 0.48$ & $2.08 \pm 1.10$ & $1.22 \pm 0.25$ \\
\hline Base sat ${ }^{\mathrm{d}}$ & $\%$ & $16.6 \pm 7.6$ & $17.9 \pm 11.4$ & $42.2 \pm 16.6$ & $31.3 \pm 12.9$ & $35.4 \pm 13.8$ & $23.4 \pm 2.5$ \\
\hline $\mathrm{Al} \mathrm{sat}{ }^{\mathrm{e}}$ & $\%$ & $59.3 \pm 15.0$ & $50.0 \pm 21.6$ & $35.5 \pm 12.8$ & $34.9 \pm 17.6$ & $43.7 \pm 15.8$ & $48.9 \pm 6.7$ \\
\hline Available P & $\mathrm{mg} / \mathrm{kg}$ & $14.8 \pm 2.0$ & $37.2 \pm 51.1$ & $14.2 \pm 7.9$ & $19.4 \pm 7.9$ & $5.7 \pm 0.4$ & $10.4 \pm 5.8$ \\
\hline Clay & $\%$ & $21 \pm 15$ & $19 \pm 3$ & $20 \pm 8$ & $18 \pm 8$ & $27 \pm 18$ & $18 \pm 2$ \\
\hline Silt & $\%$ & $18 \pm 4$ & $10 \pm 10$ & $16 \pm 4$ & $10 \pm 6$ & $20 \pm 7$ & $16 \pm 8$ \\
\hline Sand & $\%$ & $61 \pm 18$ & $71 \pm 9$ & $64 \pm 11$ & $72 \pm 12$ & $53 \pm 26$ & $66 \pm 8$ \\
\hline Bulk density & $\mathrm{g} / \mathrm{mL}$ & $1.13 \pm 0.28$ & $1.11 \pm 0.14$ & $0.97 \pm 0.16$ & $1.08 \pm 0.17$ & $0.97 \pm 0.14$ & $1.12 \pm 0.16$ \\
\hline Hardness $^{\mathrm{f}}$ & $\mathrm{mm}$ & $16 \pm 2$ & $18 \pm 2$ & $17 \pm 2$ & $15 \pm 3$ & $16 \pm 1$ & $15 \pm 2$ \\
\hline \multicolumn{8}{|c|}{ Subsurface Soil $(30-40 \mathrm{~cm})$} \\
\hline $\mathrm{pH}\left(\mathrm{H}_{2} \mathrm{O}\right)$ & & $4.94 \pm 0.19$ & $5.28 \pm 0.11$ & $4.86 \pm 0.13$ & $5.03 \pm 0.34$ & $4.86 \pm 0.15$ & $4.86 \pm 0.06$ \\
\hline $\mathrm{EC}$ & $\mu \mathrm{S} / \mathrm{cm}$ & $19 \pm 4$ & $15 \pm 2$ & $22 \pm 5$ & $20 \pm 4$ & $10 \pm 1$ & $10 \pm 2$ \\
\hline Total C & $\mathrm{g} / \mathrm{kg}$ & $10.9 \pm 4.6$ & $15.3 \pm 4.2$ & $9.9 \pm 3.8$ & $8.5 \pm 5.4$ & $9.6 \pm 4.7$ & $9.8 \pm 2.6$ \\
\hline Total N & $\mathrm{g} / \mathrm{kg}$ & $0.9 \pm 0.4$ & $1.0 \pm 0.4$ & $0.8 \pm 0.2$ & $0.6 \pm 0.2$ & $0.6 \pm 0.2$ & $0.4 \pm 0.1$ \\
\hline $\mathrm{C} / \mathrm{N}$ & & $11.7 \pm 1.3$ & $17.4 \pm 8.7$ & $12.2 \pm 4.7$ & $13.5 \pm 7.4$ & $16.1 \pm 4.1$ & $25.8 \pm 11.2$ \\
\hline CEC & $\mathrm{cmol}_{\mathrm{c}} / \mathrm{kg}$ & $3.20 \pm 2.02$ & $2.90 \pm 0.60$ & $2.40 \pm 0.59$ & $1.85 \pm 1.02$ & $3.40 \pm 2.49$ & $1.95 \pm 0.66$ \\
\hline Exch. $\mathrm{K}^{+}$ & $\mathrm{cmol}_{\mathrm{c}} / \mathrm{kg}$ & $0.02 \pm 0.01$ & $0.04 \pm 0.02$ & $0.03 \pm 0.02$ & $0.03 \pm 0.02$ & $0.03 \pm 0.02$ & $0.04 \pm 0.00$ \\
\hline Exch. $\mathrm{Mg}^{2+}$ & $\mathrm{cmol}_{\mathrm{c}} / \mathrm{kg}$ & $0.08 \pm 0.02$ & $0.05 \pm 0.01$ & $0.09 \pm 0.01$ & $0.08 \pm 0.01$ & $0.09 \pm 0.02$ & $0.06 \pm 0.01$ \\
\hline Exch. $\mathrm{Ca}^{2+}$ & $\mathrm{cmol}_{\mathrm{c}} / \mathrm{kg}$ & $0.29 \pm 0.03$ & $0.19 \pm 0.05$ & $0.32 \pm 0.02$ & $0.29 \pm 0.02$ & $0.33 \pm 0.04$ & $0.28 \pm 0.03$ \\
\hline Exch.Al ${ }^{3+}$ & $\mathrm{cmol}_{\mathrm{c}} / \mathrm{kg}$ & $0.83 \pm 0.43$ & $0.86 \pm 0.35$ & $0.82 \pm 0.17$ & $0.49 \pm 0.36$ & $1.05 \pm 0.80$ & $0.70 \pm 0.28$ \\
\hline $\mathrm{ECEC}^{\mathrm{c}}$ & $\%$ & $1.31 \pm 0.44$ & $1.13 \pm 0.40$ & $1.35 \pm 0.18$ & $0.97 \pm 0.35$ & $1.59 \pm 0.83$ & $1.14 \pm 0.32$ \\
\hline Base sat ${ }^{\mathrm{d}}$ & $\%$ & $20.3 \pm 11.3$ & $9.44 \pm 2.08$ & $23.2 \pm 6.8$ & $34.4 \pm 20.2$ & $22.1 \pm 13.8$ & $24.4 \pm 8.1$ \\
\hline $\mathrm{Al} \mathrm{sat} \mathrm{t}^{\mathrm{e}}$ & $\%$ & $60.1 \pm 12.8$ & $74.6 \pm 6.0$ & $60.3 \pm 5.5$ & $44.3 \pm 21.8$ & $61.3 \pm 13.5$ & $60.0 \pm 8.2$ \\
\hline Available P & $\mathrm{mg} / \mathrm{kg}$ & $7.9 \pm 0.6$ & $4.5 \pm 2.4$ & $1.6 \pm 0.5$ & $3.0 \pm 2.2$ & $2.1 \pm 0.3$ & $3.1 \pm 1.0$ \\
\hline Clay & $\%$ & $24 \pm 15$ & $27 \pm 6$ & $25 \pm 6$ & $17 \pm 9$ & $29 \pm 20$ & $20 \pm 4$ \\
\hline Silt & $\%$ & $18 \pm 6$ & $17 \pm 7$ & $16 \pm 4$ & $13 \pm 7$ & $18 \pm 6$ & $17 \pm 7$ \\
\hline Sand & $\%$ & $57 \pm 21$ & $56 \pm 13$ & $60 \pm 9$ & $70 \pm 14$ & $53 \pm 25$ & $63 \pm 9$ \\
\hline Bulk density & $\mathrm{g} / \mathrm{mL}$ & $1.46 \pm 0.20$ & $1.39 \pm 0.22$ & $1.45 \pm 0.13$ & $1.51 \pm 0.15$ & $1.37 \pm 0.19$ & $1.42 \pm 0.10$ \\
\hline Hardness $^{\mathrm{f}}$ & $\mathrm{mm}$ & $21 \pm 1$ & $20 \pm 4$ & $21 \pm 2$ & $22 \pm 1$ & $20 \pm 2$ & $20 \pm 1$ \\
\hline
\end{tabular}

Note: Data in this table are presented as mean \pm standard deviation

$*=$ Significant $(p<0.05)$ differences between single and multiple cultivation practices at different stages of shifting cultivation cycle

$\mathrm{SC}^{\mathrm{a}}=$ Single Cultivation; $\mathrm{MC}^{\mathrm{b}}=$ Multiple Cultivation; $\mathrm{ECEC}^{\mathrm{c}}=$ Effective CEC, sum of exchangeable bases and exchangeable $\mathrm{Al} ; \mathrm{Base}^{\mathrm{d}} \mathrm{d}^{\mathrm{d}}=$ sum of exchangeable bases in percent of $\mathrm{CEC} ; \mathrm{Al} \mathrm{sat}{ }^{e}=$ exchangeable $\mathrm{Al}$ in percent of ECEC

Hardness ${ }^{\mathrm{f}}$ was measured using Yamanaka-type push cone penetrometer

cultivation sites tended to either remain unchanged or decrease after burning, indicating that limited or no fresh (partially carbonized) plant materials were added into the soils. As reported by Kendawang et al. (2004), in sandy textured soils, fragments of SOM was not absorbed onto or closely associated with soil particles, but occurred as mineral particles which might be washed away during the rainfall after the burning practices. Our study was supported by this observation as the sand contents were negatively correlated with the amount of Total C $(\mathrm{r}=-0.767, p<0.05)$ and Total $\mathrm{N}(\mathrm{r}=-0.848, p<$ 0.01) (Fig. 2). 
From our field observation, the amount of incompletely burnt, charred branches and stems of young and mature trees left distributed over the field in single cultivation sites were observable (Fig. 3).

Young trees store relatively more nutrients in leaves and branches, whereas mature trees store more nutrients in the stem and large branches (Kyuma et al. 1985). The branches and stems from the felling did not burn completely, suggesting that some of the nutrients which stored in the plant materials were not released completely into the soils. Such condition resulted in no remarkable changes in the levels of $\mathrm{C}$ and $\mathrm{N}$ contents in single cultivation sites, although the fallow period was longer as compared to multiple cultivation sites. Additionally, decreasing Total $\mathrm{C}$ and Total $\mathrm{N}$ of soil could be ascribed to the lost Total $\mathrm{C}$ and $\mathrm{N}$ of soil through volatilization to the atmosphere when large quantities of fuel were consumed at the surface layer (Giardina et al. 2000). Therefore, soil organic $\mathrm{N}$ might be lost to the atmosphere during the thermal oxidation of organic matter in the form of oxidized $\mathrm{N}$ gases and $\mathrm{N}_{2}$, resulting to lower total $\mathrm{N}$ levels in the soils even after burning practices (Raison 1979). Andriesse and Schelhaas (1987) also pointed out that $\mathrm{C}$ disappears faster than $\mathrm{N}$ under high temperature. As the levels of soil Total $\mathrm{C}$ and Total $\mathrm{N}$ did not show significant increase after burning practices, it can be predicted that the source of $\mathrm{N}$ for rice growth mainly supplies through the inorganic form from chemical fertilizers, rather than the biomass from the burnt vegetation. After harvesting of crops, Total $\mathrm{C}$ and $\mathrm{N}$ generally decreased at the end of the cultivation cycle at both single and multiple cultivation sites. Much of the decline in soil Total
$\mathrm{C}$ and Total $\mathrm{N}$ may be attributed to the decomposition of unhumified materials (Nye \& Greenland 1960), though erosion and crop uptake decrease the level of soil Total $\mathrm{C}$ and Total $\mathrm{N}$ as well as the end of the harvesting cycle.

Content of available $\mathrm{P}$ at the surface soil in multiple cultivation sites were generally higher with a wide variation as compared to single cultivation sites. One of the multiple cultivation sites showed an extremely high value of available $\mathrm{P}$ which was $113.5 \mathrm{mg} \mathrm{P} / \mathrm{kg}$ before burning practice. Such condition could be attributed to the unused portion of $\mathrm{P}$ added by ashes or the soil samples might have been collected from the points where large amounts of burnt biomass accumulated or chemical fertilizers had been applied (Wasli et al. 2009). Similar to soil Total N, soil available $\mathrm{P}$ did not show remarkable changes after burning practices at single cultivation sites. On the other hand, multiple cultivation sites showed decrease of soil available P levels after burning practices. Contrary to studies reported by other researchers (Nakano 1978; Tulaphitak et al. 1985), available $\mathrm{P}$ of soil did not peak after burning phase in both single and multiple cultivation farmlands. As charred plant biomass was left distributed in the field, the P nutrient was not sufficient to release from the burning process. Subsequently, levels of available P of the soil decreased after the harvesting of rice crops at the end of the cycles partly attributed to crop uptake and loss through leaching as well as erosion. In multiple cultivation sites, the contents of available $\mathrm{P}$ in surface soil were relatively higher after the second cycles, suggesting that excess and immobile $\mathrm{P}$ from the fertilizers might be accumulated in these farmlands under
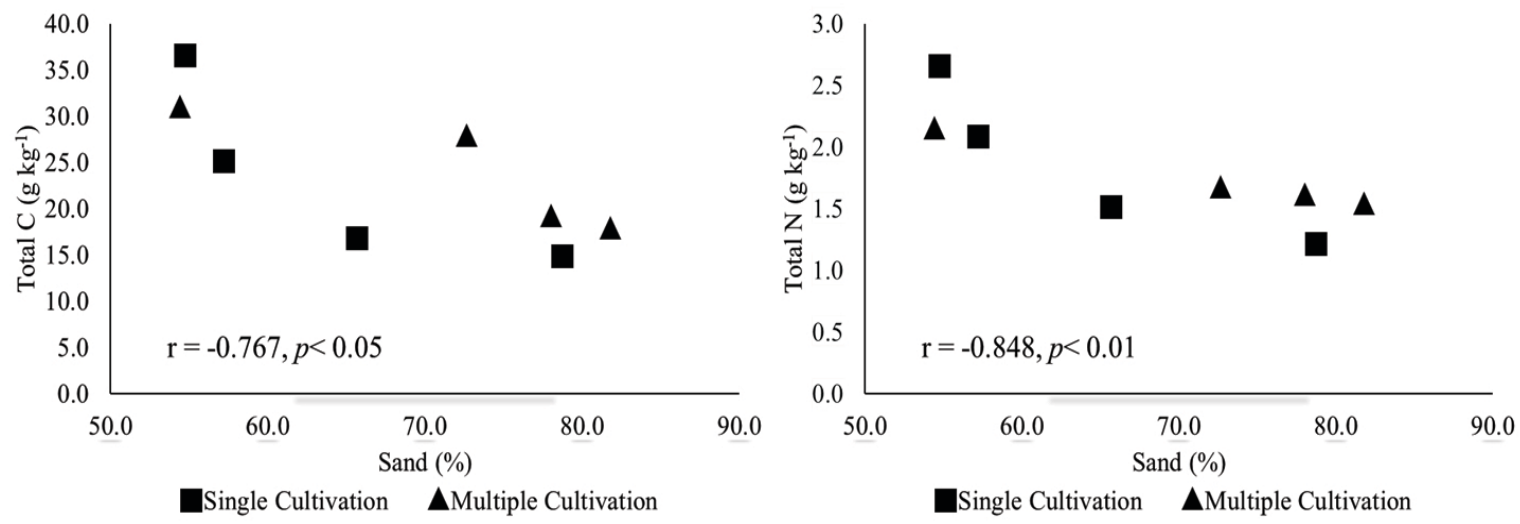

Figure 2 Relationship among sand and Total C $(\mathrm{g} / \mathrm{kg})$ and Total $\mathrm{N}(\mathrm{g} / \mathrm{kg})$ after burning at the surface soils 

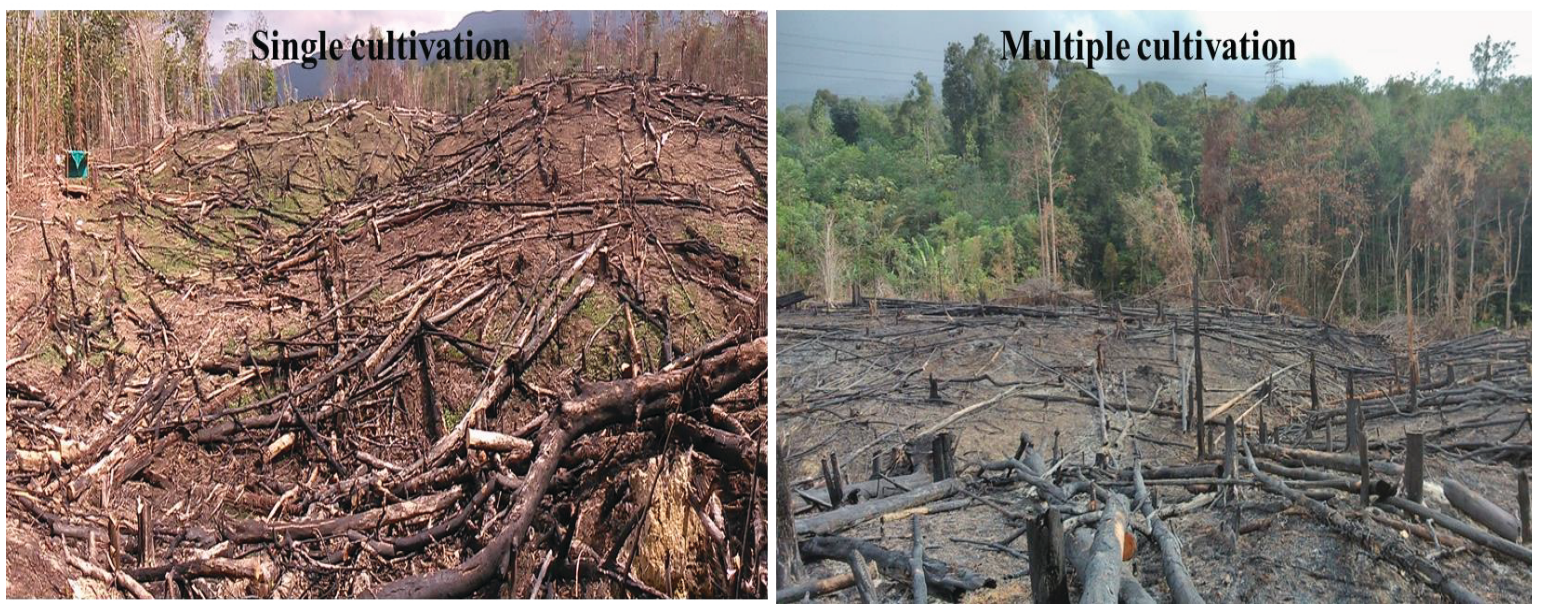

Figure 3 Charred branches of young and old vegetations scattered over the single and multiple cultivations upland rice farms

continuous cultivation practices. As for subsurface layer, the soil available $\mathrm{P}$ contents in both single and multiple cultivation sites did not vary from each other after harvesting practices, generally within the range of $1.7 \mathrm{mg} \mathrm{P} / \mathrm{kg}$ to 4.0 $\mathrm{mg} \mathrm{P} / \mathrm{kg}$.

Before the burning practice, multiple cultivation sites showed higher levels of exchangeable bases $(\mathrm{K}, \mathrm{Mg}$ and $\mathrm{Ca})$, generally ranged from 0.05 to $1.25 \mathrm{cmol}_{\mathrm{c}} / \mathrm{kg}$, primarily due to remnant ash effects and nutrients from the previous cultivations. After burning practice, the soil exchangeable bases $(\mathrm{K}, \mathrm{Mg}$ and $\mathrm{Ca}$ ) were increased to a range of 0.11 to $1.55 \mathrm{cmol}_{\mathrm{c}} / \mathrm{kg}$ in single cultivation practice from a range of 0.01 $0.70 \mathrm{cmol}_{\mathrm{c}} / \mathrm{kg}$ (before burning practice) due to the release of nutrients from dried vegetation biomass during burning. Burning usually leads to accumulation of potash which contributes to the release of macronutrients needed by plants, i.e. potassium, calcium and magnesium (Nye \& Greenland 1964; Driessen et al. 1976; Kyuma et al. 1985). Multiple cultivation sites showed little variations in exchangeable bases $(\mathrm{K}, \mathrm{Mg}$ and $\mathrm{Ca})$ after burning practices. Levels of exchangeable bases $(\mathrm{K}, \mathrm{Mg}$ and $\mathrm{Ca}$ ) slightly increased at several sites compared to single cultivation sites. Herbaceous plant indicating infertile land such aslalang (Imperata cylindrica) usually predominates after a short fallow period of less than 3 years (Tanaka et al. 2007b; Wasli et al. 2009), resulting in the restricted supply of nutrients into the soils from the burning of the aboveground biomass. After the harvesting of rice crops, the levels of exchangeable bases decreased rapidly, suggesting that the input of bases through ash effect and subsequent fertilizers application was depleted at both farmlands. Several nutrients might be lost into the environment through volatilization, runoff and leaching throughout the cycle after burning practices, the remaining ones were used by the rice crops during cultivation. At the end of the cycle $(\mathrm{AH})$, single cultivation sites showed higher levels of bases content as compared to the soils at the stage of before burning practice (BB). Although fertilizers input might affect the levels of bases at the end of the cycle, another reason could be ascribable to the existing of remnant ash effects during cultivation period (Nye \& Greenland 1964; Juo \& Manu 1996; Etsuko et al. 2004). Conversely, the levels of surface and subsurface soil exchangeable bases at some multiple cultivation sites were lowered at the end of the cycle $(\mathrm{AH})$ as compared to before burning practices $(\mathrm{BB})$. Such condition indicated that the available nutrients might not be sufficient for next cultivation after two consecutive cycles of cultivation. Thus, the farmer should consider whether to move to another farmland or increase the amount of fertilizers application as the amount of nutrient supply by the aboveground biomass could be limited after two cycles of cultivation.

\section{Rice Productivity under Current Intensified Practice of Shifting Cultivation}

In general, the yield of both single and multiple cultivation practices varied widely among the study sites. The yield of single cultivation sites ranged from $225 \mathrm{~kg} / \mathrm{ha}$ to 1,145 $\mathrm{kg} / \mathrm{ha}$ with an average of $721 \mathrm{~kg} / \mathrm{ha}$. Multiple 


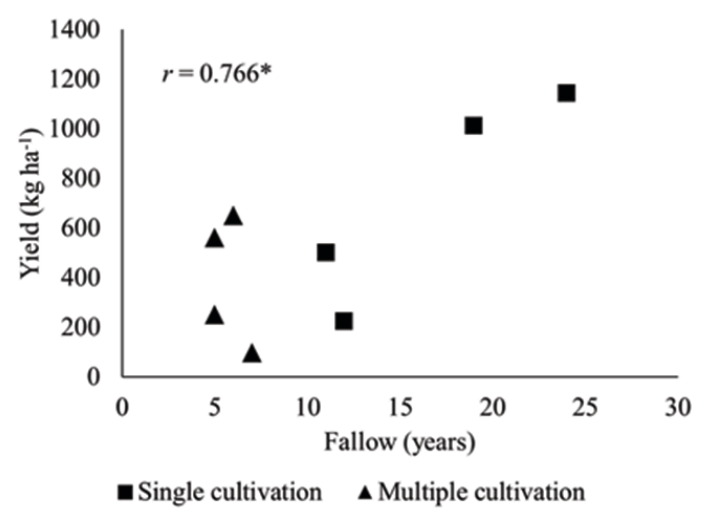

(a)

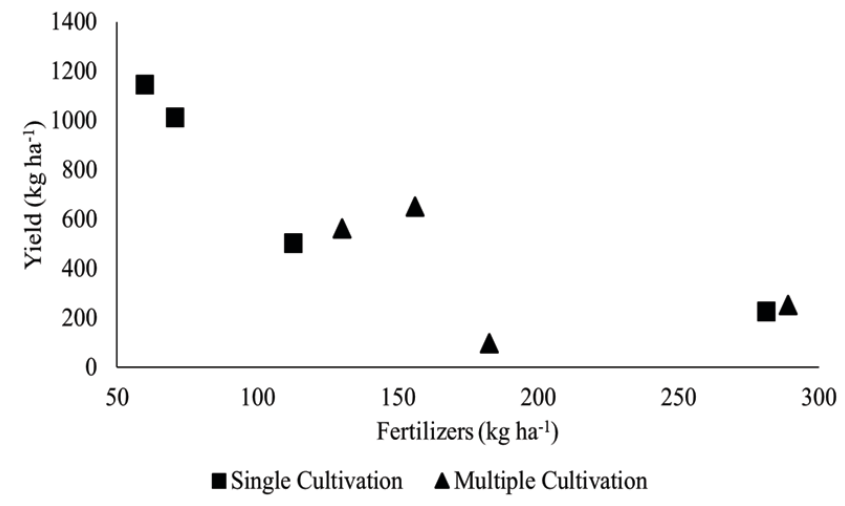

(b)

Figure 4 Relationship among upland rice yield and (a) fallow period and (b) fertilizers applied per cycle of cultivation, under single and multiple cultivation sites

cultivation sites ranged from $99 \mathrm{~kg} / \mathrm{ha}$ to 652 $\mathrm{kg} / \mathrm{ha}$ with an average of $391 \mathrm{~kg} / \mathrm{ha}$. Teng (1993) reported that the yield from traditional shifting cultivation practice of upland rice in Sarawak ranged from $460 \mathrm{~kg} / \mathrm{ha}$ to $1,184 \mathrm{~kg} / \mathrm{ha}$ with an average yield of $738 \mathrm{~kg} / \mathrm{h}$. Thus, current study showed lower yield as compared to those reported by Teng (1993). It was noticeable that no major relationship was found between rice yield and soil properties in the study area (data not shown). Figure 4(a) showed the relationship between upland rice yield and the fallow period under current single and multiple cultivation practices. In single cultivation sites, a higher yield of upland rice was observed under longer fallow length from 19 to 25 years. Lower yield of upland rice was observed under the shorter fallow length of 11 to 12 years. Rice yield under multiple cultivation sites with fallowing period of 5 to 7 years was almost similar to single cultivation sites with fallowing period of 10 to 15 years. On the other hand, Figure 4(b) showed the relationship between yield and fertilizers applied per cycle under single and multiple cultivation sites. Although the rate of fertilizers application under multiple cultivation sites were slightly higher than single cultivation sites, the upland rice production under multiple cultivation sites was still lower than that of single cultivation sites. Single cultivation required minimal amount of fertilizers i.e. less than 100 $\mathrm{kg} / \mathrm{ha}$ to produce the yield of more than 1,000 $\mathrm{kg} / \mathrm{ha}$, considering the fallow period of more than 20 years. Such condition leads to suggestions that agrochemicals, especially fertilizers application are crucial to sustain rice production under short fallow period of multiple cultivation practices.
As finding new farmlands with long fallow period is rather difficult, multiple cultivation practices with the appropriate use of agrochemicals could be one of the options to sustain the rice production on the study area. Additionally, SOM plays an important role as nutrient reservoir in determining soil productivity, further investigations should highlight the dynamics of SOM and soil microbial ecological aspects under present intensified multiple cultivation practices, especially after the burning practices. On the other hand, comprehensive nutrient management plan involving both chemical and organic fertilizers with suitable soil conservation practices can be introduced into current intensified shifting cultivation towards sustaining the rice production at the study area.

\section{CONCLUSIONS}

Current shifting cultivation has been intensified through multiple cycles cultivation with the shortening of fallow period and use of agrochemicals at upland Sabal area. There were no major significant differences between soil properties among single and multiple cultivation sites at all stages of shifting cultivation cycles within the surface and subsurface layer, except for soil $\mathrm{pH}\left(\mathrm{H}_{2} \mathrm{O}\right)$. Surface soil $\mathrm{pH}\left(\mathrm{H}_{2} \mathrm{O}\right)$ under single cultivation sites increased after the burning practice and decreased after the harvesting of the upland rice. Surface soil $\mathrm{pH}\left(\mathrm{H}_{2} \mathrm{O}\right)$ under multiple cultivation sites were acidified from the beginning until the end of the cycles. Total C and soil Total $\mathrm{N}$ of the soil did not significantly different 
between one another at both single and multiple cultivation sites. The amount of exchangeable macronutrients ( $\mathrm{K}, \mathrm{Mg}$ and $\mathrm{Ca}$ ) at the surface and subsurface soils at multiple cultivation sites showed decreasing trends of nutrients contents after subsequent cycles of cultivation as compared to single cultivation sites. Continuous cultivation without proper nutrient management plan could result in depletion and exhaustion of soil available macronutrient contents. The function of the fallow period has been substituted by the agrochemicals such as fertilizers and herbicides in sustaining the crop yield. Appropriate usage of agrochemicals could be an option to sustain the rice production for the local people under multiple cultivation practices.

\section{ACKNOWLEDGEMENTS}

This study was partially funded by Grant-in-aid of Japan Malaysian Association (JMA), MyBrain15 (MyMaster), Ministry of Education Malaysia, as well as Zamalah Graduate Scholarship and Special Fund for PhD Students (Grant No: F07(DPP55)/1334/2016(2)) from Universiti Malaysia Sarawak (UNIMAS). We thank the local people at Sabal area, especially $\mathrm{Mr}$ Ekin Empati for the hospitality and kind assistance during field visitation.

\section{REFERENCES}

Andriesse JP, Schelhaas RM. 1987. A monitoring studies on nutrient cycles in soils used for shifting cultivation under various climatic conditions in tropical Asia. III. The effects of land clearing through burning on fertility level. Agric Ecosyst Environ 19:311-32.

Armando SNL, Darwin WA, Jackie OM. 1996. Fine root mineralisation, soil organic matter and exchangeable cation dynamics in slash and burn agriculture in the semi-arid northeast Brazil. Agric Ecosyst Environ 59:191-202.

Biswas A, Alagmir M, Haque SMS, Osman KT. 2012. Study on soils under shifting cultivation and other land use categories in Chittagong Hill Tracts, Bangladesh. J Forest Res 23:261-5.

Bray RH, Kurtz LT. 1945. Determination of total, organic and available forms of phosphorus in soils. Soil Sci 59:39-45

Bruun TB, Mertz O, Elberling B. 2006. Linking yields of upland rice in shifting cultivation to fallow length and soil properties. Agric Ecosyst Environ 113:13949.

Bruun TB, de Neergaard A, Lawrence D, Ziegler AP. 2009. Environmental consequences of the demise in swidden cultivation in Southeast Asia: Carbon storage and soil quality. Hum Ecol 37:375-88.

Butt G. 1983. Semi-detailed site evaluation of Sabal Forest Reserve, Northern Half. Sarawak (MY): Forest Department Sarawak.

Coleman NT, Weed SB, McCraken RJ. 1959. Cationexchange capacity and exchangeable cations in Piedmont soils of North Carolina. Soil Sci Soc Am J $23: 146-9$

Cramb RA. 1989. Shifting cultivation and resource degradation in Sarawak: Perception and policies. Borneo Res Bull 20:22-49.

Dalle SP, de Blois S [Internet]. 2006. Shorter fallow cycles affect the availability of noncrop plant resources in a shifting cultivation system. Ecology and Society. [cited 2015 Nov 1]; 11(2). Available from: http://www.ecologyandsociety.org/vol11/iss2/art 2/

Dean WE. 1974. Determination of carbonate and organic matter in calcareous sediments and sedimentary rocks by loss on ignition, comparison with other methods. J Sed Petrol 44:242-8.

Driessen P, Buurman M, Permadhy P. 1976. The influence of shifting cultivation on a "podzolic" soil from Central Kalimantan. Bogor (ID): Soil Research Institute.

Etsuko W, Sakurai K, Okabayashi Y, Lasay N, Alounsawat C. 2004. Soil fertility and farming systems in a slash and burn cultivation area of Northern Laos. J Southeast Asian Stud 41:519-37.

Ewel J, Berish C, Brown B, Prince N, Raich J. 1981. Slashand-burn impact on a Costa Rican wet forest site. Ecology 62:816-29.

Fox J, Truong DM, Rambo AT, Tuyen AT, Cuc NP, Leisz S. 2000. Shifting cultivation: A new old paradigm for managing tropical forests. Bio Sci 50:521-8.

Funakawa S, Tanaka S, Kaewkhongkha T, Hattori T, Yonebayashi K. 1997. Physicochemical properties of the soils associated with shifting cultivation in Northern Thailand with special reference to factors determining soil fertility. Soil Sci Plant Nutr 43:66579 .

Gafur A, Borggaard OK, Jensen JR, Peterson R. 2000. Changes in soil nutrient content under shifting cultivation in the Chittagong Hill Tracts of Bangladesh. Dan J Geogr 100:37-46.

Gee GW, Bauder JW. 1986. Particle-size analysis. In: Klute A, editor. Methods of Soil Analysis, Part 1. Madison (US): American Society of Agronomy (ASA) and Soil Science Society of America (SSSA). p. 383-411. 
Giardina CP, Sanford PL, Dǿckersmith IC, Jaramillo VJ. 2000. The effects of slash and burning on ecosystem nutrients during land preparation phase of shifting cultivation. Soil Sci Plant Nutr 220:247-60.

Hölscher D, Ludwig B, Moller RF, Folster H. 1997. Dynamic of soil chemical parameters in shifting agriculture in Eastern Amazon. Agric Ecosyst Environ 66:153-63.

Ichikawa M. 2004. Relationship among secondary forests and resource use and agriculture, as practised by the Iban of Sarawak, East Malaysia. Tropics 13:269-86.

Ickowitz A. 2006. Shifting cultivation and deforestation in tropical Africa: critical reflections. Dev Change 37:599-626.

Juo ASR, Manu A. 1996. Chemical dynamics in slash-andburn agriculture. Agric Ecosyst Environ 58:49-60.

Kendawang JJ, Tanaka S, Ishihara J, Shibata K, Sabang J, Ninomiya I. 2004. Effects of shifting cultivation on soil ecosystems in Sarawak, Malaysia: Slash and burning at Balai Ringin and Sabal experimental sites and effect on soil organic matter. Soil Sci Plant Nutr 50:677-87.

Kendawang JJ, Tanaka S, Shibata K, Yoshida N, Sabang J, Ninomiya I, Sakurai K. 2005. Effects of shifting cultivation on soil ecosystems in Sarawak, Malaysia. III. Results of burning practice and changes in soil organic matter at Niah and Bakam experimental sites. Soil Sci Plant Nutr 51:515-23.

Kleinman PJA, Pimentel D, Bryant RB. 1995. The ecological sustainability of slash and burn agriculture. Agric Ecosyst Environ 52:235-49.

Kumada K, Ohta S, Arai S, Kitamura M, Imai K. 1985. Changes in soil organic matter and nitrogen fertility during the slash-and-burn and cropping phases in experimental shifting cultivation. Soil Sci Plant Nutr 31:611-23.

Kuo S. 1996. Phosphorus. In: Sparks DL, Page AL, Helmke PA, Loeppert RH, Soltanpour PN, Tabatabai MA, ... Sumner ME, editors. Methods of Soil Analysis. Part 3 - Chemical Methods. Madison (US): Soil Science Society of America (Inc) and American Society of Agronomy (Inc). p. 869-919.

Kyuma K, Pairintra C. 1983. Shifting cultivation: An experimental at Nam Phrom, Northeast Thailand, and its implications for upland farming in the monsoon tropics. Kyoto (JP): Faculty of Agriculture, Kyoto University.

Kyuma K, Tulaphitak T, Pairintra C. 1985. Changes of soil fertility and tilth under shifting cultivation. I. General description of soil and effect of burning and soil characteristics. Soil Sci Plant Nutr 31:22738.

Mertz O. 2002. The relationship between fallow length and crop yields in shifting cultivation: A rethinking. Agrofor Syst 55:149-59.

Meteorological Department 2014. Weather data 2004-2013. Kuching (MY): Meteorological Department.
Nakano K. 1978. Ecological study of swidden agriculture at a village in Northern Thailand. J Southeast Asian Stud 16:411-46.

Nielson U, Mertz O, Noweg GT. 2006. The rationality of shifting cultivation systems: Labour productivity revisited. Hum Ecol 34:210-8.

Nye PH, Greenland DJ. 1960. Commonwealth bureau of soils. Farnham (UK): Commonwealth Agricultural Bureau.

Nye PH, Greenland DJ. 1964. Changes in the soil after clearing tropical forest. Plant and Soil XXI 1: 10112.

Raison RJ. 1979. Modification of the soil environment by vegetation fires, with particular reference to nitrogen transformations: A review. Plant Soil 51:73-108.

Soil Survey Staff. 1999. Soil taxonomy: A basic system of soil classifications for making and interpreting soil surveys. Washington (US): United States Department of Agriculture.

Tanaka S, Funakawa S, Kaewkhongkha T, Hattori T, Yonebayashi K. 1997. Soil ecological study on dynamics of $\mathrm{K}, \mathrm{Mg}$ and $\mathrm{Ca}$ and soil acidity in shifting cultivation in northern Thailand. Soil Sci Plant Nutr 43:547-58.

Tanaka S, Ando T, Funakawa S, Sukhrun C, Kaewkhongkha T, Sakurai K. 2001. Effect of burning on soil organic matter content and $\mathrm{N}$ mineralisation under shifting cultivation system of Karen people in northern Thailand. Soil Sci Plant Nutr 47: 547-58.

Tanaka S, Kendawang JJ, Ishihara J, Shibata K, Kou A, Jee A, ... Sakurai K. 2004. The effects of shifting cultivation on soil ecosystems in Sarawak, Malaysia. II Changes in soil chemical properties and runoff water at Balai Ringin and Sabal experimental sites. Soil Sci Plant Nutr 50:689-99.

Tanaka S, Wasli ME, Seman L, Jee A, Kendawang JJ, Sakurai K, Morooka Y. 2007a. Ecological study on site selection for shifting cultivation by the Iban of Sarawak, Malaysia. A case study in the Mujong River area. Tropics 16:357-70.

Tanaka S, Wasli ME, Seman L, Jee A, Kendawang JJ, Sakurai K, Morooka Y. 2007b. Soil properties of secondary forests under shifting cultivation by the Iban of Sarawak, Malaysia in relation to vegetation condition. Tropics 16:385-98.

Teng SC. 1993. Shifting cultivation of hill padi - A traditional method of utilizing and managing natural soil fertility for rice production in Sarawak. Kuching (MY): Agriculture Department of Sarawak.

Tulaphitak T, Pairintra C, Kyuma K. 1985. Changes in soil fertility and tilth under shifting cultivation. II. Changes in soil nutrient status. Soil Sci Plant Nutr 31:239-49. 
Wasli ME, Tanaka S, Kendawang JJ, Seman L, Unang B, Lat J, ... Sakurai K. 2009. Vegetative conditions and soil fertility of fallow lands under intensified shifting cultivation systems in Sarawak, Malaysia. Tropics 18: $115-126$.
Wasli ME, Tanaka S, Kendawang JJ, Abdu A, Lat J. 2011. Soils and vegetation condition of natural forest and secondary fallow forests within Batang Ai National Park boundary, Sarawak, Malaysia. Kuroshio Sci 5:67-76. 